\title{
A style study of the Apostle Paul's communication with Festus and Agrippa: The use of literary Koine Greek in Acts 25:14-22; 26:1-29
}

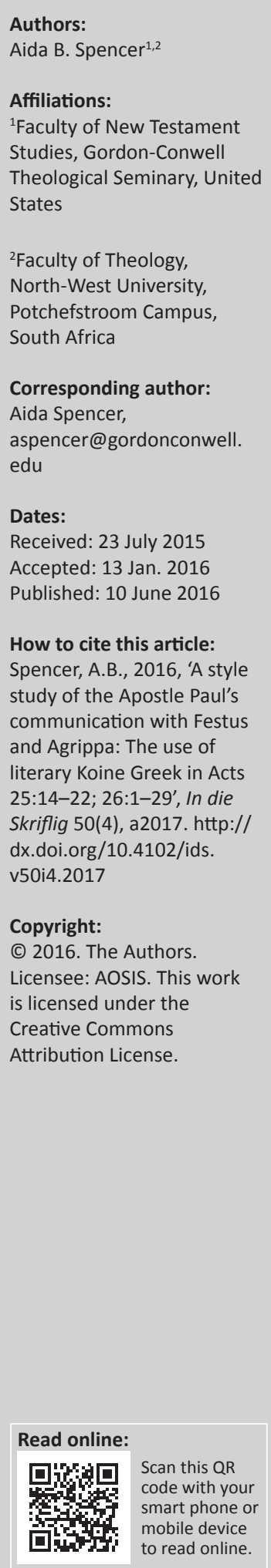

This article defines style, stylistics and literary koine Greek and analyses the literary koine Greek employed in Luke's recording of the Apostle Paul's court case at Caesarea in Acts 25:14$22 ; 26: 1-29$. The principles and methodology in stylistics are explained and an overview of some of the style studies in the last 30 years is made. Paul demonstrates a literary style of Greek when speaking with Festus and Agrippa. Stylistics defines 'style' as the choices an author makes (whether conscious or subconscious) amongst linguistic possibilities (usually but not always a choice amongst grammatical possibilities). In grammatical studies, rhetoric is the manner of writing. Style study helps to observe the author's emphasis, analogies and message, and helps with the appreciation of communication.

\section{Introduction}

In this article, an in-depth stylistic study of Acts 25:14-22; 26:1-29, the court case of the Apostle Paul at Caesarea with Procurator Porcius Festus and King Marcus Iulius Agrippa II, will be done by employing some techniques used in stylistics. Stylistics is interdisciplinary and comparative. As part of my doctoral studies, I employed stylistics to do a comparative study of three New Testament passages (Spencer 1984). The principles and methodology of stylistics will be explained, stylistics to New Testament rhetorical criticism will be compared, an overview of some of the style studies will be provided since the publication of my dissertation, literary koine Greek will be defined, and a close reading of the lexical substitutions and progression of thought in the speeches in Acts 25:14-22; 26:1-29 will be done. Paul's demonstration of a literary style of Greek when speaking with Festus and Agrippa will be observed.

\section{What is stylistics and style?}

In this article, stylistics denotes the use of linguistics as a tool of literary criticism by which to investigate the aesthetic effects of language. Stylistic analysis matches one text against another text as a contextually related norm. The secondary text(s) can serve as a control to hold constant whatever are to be the critical variables. For an extensive study, each example should have at least 500 English or at least 300 Greek words. In stylistics, 'style' denotes the choices an author makes (whether conscious or subconscious) amongst linguistic possibilities (usually but not always a choice amongst grammatical possibilities). If language is a set of conventions for the expression of thought by the members of a given speech community, the individual has a choice of means for expressing his or her thoughts. As linguistics is a descriptive rather than a prescriptive science, stylists can be simply descriptive. Style is largely subconscious, unique, felt, but not always readily observable. In contrast, rhetoric is a conscious mode of persuasion (Spencer 1984:14-17).

In my earlier stylistic study of 2 Corinthians 11:16-12:13, Philippians 3:2-4:13 was chosen as a comparable passage to 2 Corinthians 11. In both passages, Paul responds to his Judaizing opposition. The contrast I discovered between 2 Corinthians and Philippians has to do with the receptiveness of the readers to Paul: the Corinthians not being especially receptive whilst the Philippians are more receptive. The third passage, Romans 8:9-39, was helpful as a control passage. It does not discuss the Judaizing opponents and its Roman audience has little or no relationship to Paul, yet this letter was written approximately at the same time as 2 Corinthians (Spencer 1984:4). The general theme of suffering is similar in all three passages: highlighting both external difficulties as a part of the Christian life and the manner in which God can empower people during such times. In addition, all three congregations experienced a problem of disunity, albeit from different causes. The goal was to see if Paul varies the style of his writing to assist communication to different communities. The answer was positive. In conclusion the observation 
has been made that, to the Corinthians, Paul came as a warrior to conquer. As a warrior, he seeks to pierce his opponents' armour. To the Romans, Paul came as a diplomat to persuade. As an ambassador, he seeks to gain the confidence of his hearers. To the Philippians, Paul came as a father to exhort. As a father, he assumes he is already respected and is given authority to urge directly (Spencer 1984:4, 93-94, 146).

Aspects of stylistics can also be used in exegetical studies of single passages. For instance, sentence changes, logical diagrams and imagery may be studied. Basic data may be gathered from ancient Greek stylists such as Demetrius, Longinus and Aristotle, augmented by advanced grammar books that discuss style such as those by Robertson (1934), Blass, DeBrunner and Funk (1961), Turner (1976) and Dover (1960), supplemented by my own style studies. Of the 10 stylistic operations, some have been helpful even when no comparative passage is employed, for example the study of:

1. Sentence changes, which include figures of speech and unusual word order classified as addition, subtraction, substitution and transposition of the common sentence. For example, when words like 'and' are repeated as in polysyndeton, that would be an addition change. If no conjunctions connect words as in asyndeton, an omission is occurring. Substitution changes include figures of speech such as metaphor; syntactical changes such as by an active or passive verb; and lexical changes such as with a popular or learned word. Changing the usual word order is an example of a transpositional change.

2. Logical diagrams, which is the classification of the manner in which the thoughts of each sentence precede one another. This manner of diagnosis has been developed in recent years in discourse analysis. In stylistics, however, logical diagrams analyse sentences. A paragraph can be subdivided into eight basic propositions: initial, additive, adversative, alternative, explanatory, illustrative, illative and causal. ${ }^{1}$

3. Imagery, the analysis of metaphor, simile, personification and synecdoche, which is always significant. Image is a thing that represents something else (Spencer 1984:33). Aristotle (Poet. 22.16-17) reminds us that the greatest capacity is the apt use of metaphor. To use metaphor well is to discern similarities. Images, too, must be studied in regard to their function in their own literary and historical contexts (Spencer 1984:34).

\section{Stylistics compared to New Testament rhetorical criticism}

In rhetorical criticism, an interpreter can pay more attention to an in-depth reading of the text, the smaller aspects of style and a detailed observation of what is unique and particular. Stylistics would fit in this line of tradition and study of word order, figurative or literal language, and other choices

1.The initial, illative, explanatory and illustrative propositions convey the basic cognitive message of a text (Spencer 1984:31) amongst linguistic possibilities or an interpreter can pay more attention to the genre, the larger aspects of style, what is common and general (Longman 1987:76). The form is classified with its family of forms, resulting in observation of what is common to all. In the first line of tradition, in the microcosm is the macrocosm. In the second line of tradition, in the macrocosm is the microcosm (Spencer 1991:239).

Literary studies in the New Testament tend to be done more on genre than on figures of speech. Traditionally, in New Testament studies, literary criticism also often becomes a means to an end: to understand the historical process. Analysis of style of writing may become a means to attempt to determine sources or authorship. In genuine literary criticism the critic is concerned with the literary text for its own sake. Moreover, scientifically, large examples of writing are needed to use style to determine authorship. For example, in the classic study of the Federalist papers by Alexander Hamilton, John Jay and James Madison (1787-1788), Mosteller and Wallace (1963) had 94000 and 114000 word examples of undisputed authorship with which to compare the disputed writings. ${ }^{2}$ The whole New Testament has less than 180000 English words and 140000 Greek words. ${ }^{3}$ Each author within the New Testament has far too few words to sustain a responsible conclusion on authorship from the basis of style of writing. Therefore, such studies would not be considered as literary studies, because style is used as a means to another historical question.

More and more scholars and students are now moving in the opposite direction, using literary criticism of the Bible whilst ignoring the Bible's historical nature. Although the Bible clearly contains fiction such as parables, the Bible itself does not claim to be fiction. It claims to record historical events. For example, Paul tells the Corinthians:

If Christ has not been raised, then our proclamation has been in vain and your faith has been in vain. We are even found to be misrepresenting God, because we testified of God that he raised Christ - whom he did not raise if it is true that the dead are not raised. (1 Cor 15:14-15, NRSV)

John begins his letter: 'We declare to you what was from the beginning, what we have heard, what we have seen with our eyes, what we have looked at and touched with our hands' (1 Jn 1:1, NRSV). Luke wrote of his recent events 'as they were handed on to us by those who from the beginning were eyewitnesses' (Lk 1:2, NRSV). Accordingly, I treat the Bible as an historical document with literary features (Spencer 1991:236-237).

In my studies, questions of what is said, is separated from how something is said and then the two is compared. Style ('how') and its impact on the content ('what') is analysed.

2.Neumann (1990:215) found that the use of hapax legomena is 'among the least effective indices' for determining authorship from style. In my own study of Paul's effective indices' for determing authorship from style. In my own study of Paul's writing, the only consistent variable was the percent of monosyllables vs.
polysyllables (Spencer 1984:183).

3.The King's James version (KJV) has 790868 words. The 28th edition of the Novum Testamentum Graece, including words in double brackets, has 138013 words. Testamentum Graece, including words in double brackets, has 138013 words.
Thanks to reference librarian, James Darlack at Goddard Library of Gordon-Conwell Theological Seminary, Hamilton, MA for calculating these lengths using Bible Works. 
Literary analysis should never supersede historical analysis when you have an historical document. Literary studies are one aspect of comprehending a Bible text, a complement to historical study.

Nevertheless, as a literary communication, the New Testament (and Hebrew Scriptures) lend themselves to many techniques of literary analysis. Literary criticism includes the analysis of how form is related to meaning and the aesthetic effects of language (Spencer 1991:238, 245).

\section{Contemporary examples of literary studies of the New Testament}

James Muilenburg and Phyllis Trible had brought academic attention to the smaller aspects of stylistic analysis of the Old Testament in the 1960s (Spencer 1984:8). Then more scholars drew attention to ancient rhetorical criticism and the New Testament, including George Kennedy in 1984. For example, he analyses 2 Corinthians as judicial rhetoric, because Paul is seeking to persuade the audience (Kennedy 1984:87-89). Shortly after, Aune (1987) dealt with the question of genre from a historical perspective and attempted to classify the Gospels and the Letters in their respective genres. Later Betz (1979; 1985) suggested Galatians as an example of an apologetic letter genre, 2 Corinthians 8 as an administrative letter, and 2 Corinthians 9 as an advisory letter. Many scholars have pointed out that Romans 16:1-2 has affinities to ancient letters of recommendation (Spencer 1984:94; 1991:241).

Caird (1980:153-155) highlighted the metaphor, mentioning that metaphors can have varying degrees of correspondence between vehicle and tenor, and varying degrees of development. Understanding the richness of many New Testament passages can be increased by analysing to what degree a metaphor is developed (e.g. Collange 1973:118; Spencer 1984:201). ${ }^{4}$ Many individual studies have delved into analysis of the Apostle Paul's use of imagery (e.g. Byron 2003; Finlan 2004; Lyall 1984; ${ }^{5}$ McNeel 2014; Williams 1999). Collins (2008:vii) has written a letter by letter study of Paul's use of metaphor to demonstrate Paul's goal: 'to persuade his audience of the truth of the gospel in various sets of circumstances and in its many ramifications'. Watson (2010) agrees that:

Paul uses style as a conscientious rhetor would use it to meet the exigencies of his rhetorical situation ... He uses style to accomplish his goals of persuasion and dissuasion, affirmation and reorientation. (p. 133)

Studies in ancient rhetorical theory and Paul have blossomed in the last 20 years (e.g. Anderson 1998; Porter \& Stamps

4.Cosby $(1988: 258,261,273)$ has published a fine close reading of Hebrews $11 . \mathrm{He}$ claims that the writer uses language forcefully and artistically. In 1998, InterVarsity Press published its encyclopedic exploration of the images, symbols, motifs, Press published its encyclopedic exploration of the inages, symbols, motifs, metaphors, figures of speech, and literary patterns of the Bible in the Dictionary of Biblical Imagery. I was invited to write articles on 'Dancing' and 'Peace' (Ryken, Wilhoit \& Longman 1998:188-189, 632-633). Ryken (1992) has himself written a
helpful literary introduction to the Bible.

5.Lyall (1984:239) concludes that Paul 'makes the most extensive use of legal metaphors in the New Testament Epistles'.
1999; Sampley \& Lampe 2010; Stanley 2004; Witherington 2009). Without a doubt the New Testament has at least three genres: letter, narrative (Gospel, Acts) and apocalypse (Revelation). ${ }^{6}$ The New Testament books contain parable and possibly poetry. However, sometimes genre critics can force New Testament writings into forms that do not completely fit. ${ }^{7}$ Although the classification of genre should be welcomed, the application of such classification should be done carefully with attentiveness to the integrity of the individual New Testament book. What is essential is to study a book in light of its overall purpose as a basis for all further study of any part or passage (Spencer 1991:241-243).

Studying the larger aspects of style tends to be more deductive: analysing the goal and elements of a genre or form and then applying these common characteristics to a specific book or passage. In contrast, studying the smaller aspects of style tends to be more inductive: reading and rereading a book or passage until an intuitive hypothesis is formed about the significance of how a particular stylistic feature relates to the whole. Both approaches have integrity and value. Probably some people tend to accentuate the general and common, and others the unique and particular. Nevertheless, the two approaches need to inform one another graciously (Spencer 1991:244).

\section{Style study of Acts 25:14-22; 26:1-29}

One aspect of stylistics I did not venture into during my dissertation study was the lexical aspect of substitution changes: Is the author using popular or learned vocabulary, foreign or native, formal or informal? (Spencer 1984:25) It is difficult to ensure accuracy in such subtle analyses whilst studying a language used almost 2000 years ago. However, after 30 years of teaching the New Testament and using the help of advanced Greek grammar books, I would like to venture briefly into analysis of the literary style in Luke's recording of the court case of Paul's at Caesarea in Acts 25:14-26:29. ${ }^{8}$

A large group of people was present. During this formal case, Festus, Agrippa and Paul appear to use literary koine (the polite speech of orators, historians, philosophers, poets, public documents preserved in inscriptions and cosmopolitan scholars) as opposed to the popular or vernacular speech, the normal speech of the people. In literary koine, the speaker may use abstract nouns, ${ }^{9}$

6.Ryken (1987:18) agrees that the New Testament has three main genres: narrative or story, letter or epistle and vision or apocalypse.

7.Part of the danger of looking at form is to accentuate the common rather than the unique. The ancient Hebrews, for example, did not differentiate between parable, allegory, and saying as we do. The Hebrew word mashal refers to sayings (Dt 28:37), proverbs (1 Sm 10:12) and allegories (Ezk 17:1-24)

8.Luke may have been one of those in the crowd listening (25:23-24; 26:29). The pronoun we, showing Luke's presence, appears again in the very next chapter when Paul is about to depart for Rome. The grammarian, Robertson (1930:440), considers that 'Luke was surely present and witnessed' the grand spectacle of the court 'with Paul as chief performer'. However, for those who think that Luke wrote rather than recorded all the speeches in Acts, here he did a marvelous job of varying his words to show the more elevated language of the court and Paul's attempt to be an ambassador of the good news.

9. Examples of abstract nouns are biōsis [way of life] and anakainōsis [renewal]. The article tends to be omitted (Robertson 1934:152, 794). 
denominative verbs, ${ }^{10}$ new adverbs, optative moods, passive voices, and Ionic or classical words. ${ }^{11}$

When King Agrippa and Bernice arrive in Caesarea, procurator Festus lays Paul's case before the king. Interspersed in their speeches is literary Greek, including the optative mood and the passive verb. In addition to this being a formal case, Festus is a literary person who wants to impress Agrippa. Acts 25, ${ }^{12}$ and further, refers to Herod Agrippa II (Marcus Iulius Agrippa), son of Herod Agrippa I (mentioned in Ac 12), began ruling in 50 CE. Agrippa II was reared in Rome under Emperor Claudius. In 56 and 75 CE Nero gave him more land. In appreciation, Agrippa changed the name of Caesarea Philippi to Neronias and called himself philokaisar (Josephus, Ant. xx.7.1; Bruce 1990:490-491). Agrippa was responsible for appointing the high priests at the temple in Jerusalem. He remained loyal to the Roman Empire even through the War of Rome against Jerusalem (66-74 CE). He attained praetorian rank. Julia Berenice (Bernice) (Danker et al. 2000:174), born in 28 CE, was the daughter of Herod Agrippa I and sister to Agrippa II.

When Porcius Festus arrived in $60 \mathrm{CE}$, Judea was afflicted by robbers, zealots and insurrectionists (Josephus, Ant. 20. 8.9-11). Festus sent forces, but they were not as brutal as those of his predecessor, Felix. ${ }^{13}$ When Agrippa II broke the Jewish ritual laws to look over the temple, he and Festus were in agreement to pull down a wall that the Jews had built in response. The Jews were furious at their intention and sent an emissary to plead their case to Nero (Schürer 1973:475). These were difficult times, and delicacy in language was needed to win over potential adversaries.

The apostle Paul shows a more literary style of language when speaking with governors Felix and Festus. ${ }^{14}$ Festus begins with the literary koine and Paul meets him at his level. He became all things to all people that he might save some (1 Cor 9:22). In Paul's conversation with Festus and Agrippa, in the space of two chapters (25:14-26:29), four optatives are used $(25: 16,20 ; 26: 29)$. Paul also used an optative in speaking to Felix (24:19). The optative is very rare in the vernacular koine. It is used only 67 times in the New Testament. The optative is a somewhat weaker subjunctive expressing

10.Denominative verbs are verbs made from nouns, such as timaō from timē. The simple denominatives end in - $a \bar{o},-e \bar{o},-e u \bar{o},-a z \bar{o},-i z \bar{o}$ (Robertson 1934:147).

11.The old Ionic-Attic was the archaic Greek tongue. The Attic arose from the lonic, the language of drama, philosophy and oratory. Prassō, for example, is an Ionic form that occurs in 25:25:26:9, 20, 26 (Moulton 1908:197; Robertson 1934:16-17, 50, 57-58, 62, 84, 210-211, 907, 938; Witherington 1998:737).

12.Further references to Acts will be indicated only by chapters and verses.

13.Festus' predecessor, Marcus Antonius Felix, was not so cultured. He attracted Drusilla, daughter of Agrippa I, whilst she was still married to Azizus. He had a conflict with the high priest Jonathan and had him killed. Felix attacked the Jews in Caesarea who were fighting the Syrians about equal rights. The Jews then accused Felix before the emperor. Felix also caught and killed many insurrectionists and robbers (Josephus, Ant. 20. 7.2-3; 8.5, 9).

14. Robertson $(1934: 86,106)$ considers Paul uses the literary koine in this speech before Agrippa, in his address at Mars Hill, and in Ephesians and Romans (see also Blass et al 1961:2). Withering (1998:736) describes Paul's speech in (see also Blass et al. 1961:2). Witherington (1998:736) describes Paul's speech in 26:1-32 as 'perhaps the most elegant of all the speeches in Acts, reflecting careful preparation and attention to elements of style'. Polhill (1992:499) agrees that this speech is cast in the most elevated, cultured language' in Acts. Williams (1990:415) add that Paul's speech is 'the most polished of all the speeches, adorned with rare words and marked by an elaborate, even grandiose, style'.
TABLE 1: Occurrences of the optative mood in the New Testament.

\begin{tabular}{llc}
\hline New Testament & Occurrences & Number \\
\hline Acts & $\begin{array}{l}\text { Narrator (7), Paul (4), Festus (3), } \\
\text { Peter (1), Ethiopian (1), Athenian } \\
\text { philosophers (1)† }\end{array}$ & 17 \\
Luke & & 11 \\
Paul's letters & 31 \\
Mark & 1 \\
Jude & 2 \\
Peter's letters & 4 \\
Hebrews & 1 \\
\hline
\end{tabular}

Source: Author's own work

$\dagger, 1.7$ or $41 \%$ are used by the narrator (Ac 5:24; $10: 17 ; 17: 11 ; 20: 16 ; 21: 33 ; 27: 12,39$ ); 4 or $24 \%$ by Paul $(17: 27 ; 24: 19 ; 26: 29) ; 3$ or $18 \%$ by Festus $(25: 16,20)$, once by Peter $(8: 20)$, once by the Ethiopian (8:31), and once by the Athenian philosophers (17:18)

potential, wish or hesitating deliberation. It is the mood of possibility. Luke in the Gospel and Acts uses the optative 28 times and Paul 31 times in his letters $-88 \%$ of the total New Testament uses (Robertson 1934:106, 936-940). Of the 17 uses of the optative in Acts, $24 \%$ of them are used in this one conversation of Festus and Paul.

In the conversation in Acts, Festus begins his talk to Agrippa, recorded as three extended sentences in Acts (25:14-16, 17-18, 20-21):

A certain man is left by Felix, a prisoner, concerning whom, when I came into Jerusalem, they informed, the high priests and the Jewish elders, demanding against him a conviction, to whom I answered that it is not a custom for Romans to pardon any person before the one being charged may have a face to face [with] the chargers and might receive an opportunity of a defence concerning the charge. (25:14b-16, [author's literal translation of speech]).

In the space of the introduction, Festus uses three optatives: echoi, laboi, bouloito $(25: 16,20)$, including prin e plus the optative instead of the more common subjunctive an echei. This is the only example of the optative in a temporal clause in the New Testament (Robertson 1930:435, 1934:970). ${ }^{15}$ Festus' language is very indirect. After the narrator's introduction, he says: 'A certain man is left by Felix, a prisoner' (25:14). He follows with an extended adjectival clause describing the prisoner: 'concerning whom, when I came into Jerusalem, they informed', then he adds the subject: 'the high priests and the Jewish elders', followed by an adjectival participial phrase: 'demanding against him a conviction' (25:15). He then adds another adjectival clause:

to whom I answered that it is not a custom for Romans to pardon any person before (prin e) the one being charged may have (echoi) a face to face (with) the chargers and might receive (laboi) an opportunity of a defence concerning the charge. (25:16, [authors's own emphasis])

The first sentence includes a genitive absolute: 'when I came into Jerusalem'. The genitive absolute may be used in literary koine as an indirect way to express a finite verb when referring to time. The Attic orators highly developed the use of the absolute. ${ }^{16}$

15.Barrett (1998:1137) acknowledges the presence of 'classical Greek' on the lips of these 'educated men'.

16.It could make the participial clause more prominent (Robertson 1934:513, 11311132). 
The second sentence begins with another genitive absolute (25:17). Festus continues:

Therefore, when they travelled together here, without losing any time, afterward (to show Agrippa how diligent a procurator he was), having sat upon the judgment seat, I commanded to be brought (aorist passive infinitive) the man. (25:17, [authors's own emphasis])

Now, he adds another adjectival clause:

concerning whom, the accusers, having been established (aorist passive participle), no reason they are bringing of which I myself am suspecting crimes (25:18), but some issue concerning their own religion - they are having against him - and concerning some dead Jesus whom Paul claimed lives (v. 19), but I myself being at a loss concerning these issues, I am saying if he might want (bouloito) to go into Jerusalem and there to be judged concerning these things (v. 20). But, when Paul appealed to keep him in custody for a decision from the Augustus (most worthy of reverence Emperor) ${ }^{17}$ I commanded him to be kept (aorist passive infinitive) in custody until when I will send him to Caesar. (25:21, [author's own emphasis])

Festus has used several classical words, appropriate for literary koine and for this formal occasion. ${ }^{18}$ Festus' speech might be categorised as a careful administrative complicated (or convoluted) polite formal speech-perfect for a politician trying to please everyone.

Agrippa then replies to Festus, using the imperfect for courtesy instead of the present active indicative (Bruce 1990:493; Robertson 1930:437): 'I myself also am wishing to hear the person' (25:22), to which Festus replies with the definitive brief affirmation: 'Tomorrow you will hear him!' (25:22). On the next day, King Agrippa tells Paul in an indirect formal way, using the present passive: 'It is permitted to you concerning yourself to speak' (26:1).

Paul then begins his address ${ }^{19}$ (exordium) to Agrippa, Bernice and Festus with the captatio benevolentiae (Robertson 1930:442; Winter 1993:324-327), affirming the listener:

Concerning all of which I am being accused by Jews, King Agrippa, I have considered myself ${ }^{20}$ blessed before you, I am going to defend myself today, especially you being an expert of all the Jewish customs and also controversies, for this reason I ask you patiently to hear me. $(26: 1 b-3)$

Paul introduces his case in 26:4, where he changes the nature of the charge. Despite complaints, he explains he has not committed any offense against any Jewish laws or the temple or the emperor. Rather, his real 'offense' is to hope in the resurrection (26:4-8). In this introductory sentence, Paul

17.The Greek term Sebastos has the notion of worship. It fell in with the tendency toward emperor worship (Robertson 1930:437).

18.Katadikē [sentence of condemnation] (25:15), anabolē [delay] (v. 17), and huponoeō [suspect] (v. 18) (Bruce 1990:492; Robertson 1930:435-436).

19.Commentators differ over the meaning of Paul's extension of hand: 'a respectful salutation to the king' (Bruce 1990:496) or a 'dramatic oratorical gesture' (Robertson 1930:442); 'assuming the pose of an orator' (Polhill 1992:499; Schnabel 2012:1001; Witherington 1998:738).

20.The perfect ègemai with present meaning is a literary and classical touch (Barrett 1998:1151; Bruce 1990:497; Moulton 1908:148). includes a more literary classical form of the verb oida, [to know] (isasi instead of the more common Hellenistic oidasin) (Barrett 1998:1151; Bruce 1990:497; Robertson 1930:443-444):

Indeed my manner of life from a youth, the one happening from the beginning among my people and in Jerusalem, all the Jews know (oida), knowing me beforehand (proginoskō) for a long time, if they may want to testify, that, according to the strictest ${ }^{21}$ party of our religion, I have lived, a Pharisee. (26:4, [author's own emphasis])

Paul's lengthy testimony continues with the narratio or statement of the case and confirmato or proofs in 26:9-21 and is summarised (peroratio) in verses 21-23. He describes his past history of persecution of Christians (26:9-11), why he changed and his commission (v. 12-18) and his change of action (v. 19-20). In the conclusion, Paul summarises his argument, but also refocuses from defence of himself to defence of Jesus as the Messiah who would suffer, but be resurrected as a light to both Jews and Gentiles. Paul directs his testimony in 26:4-2322 to King Agrippa, speaking to him quite directly, but Procurator Festus interrupts Paul in a loud voice, yelling: 'Mad, Paul; your great learning is turning into madness' (v. 24).

Paul now regroups and returns to literary koine with perfect courtesy to demonstrate that he is quite sane and cultured:

I am not mad, most excellent Festus, but truthful and sound words I declare, for the king knows concerning these things, to whom also freely I speak, for I am persuaded none of these things are hidden; for this is not accomplished in a corner. You believe, King Agrippa, in the prophets. I know that you believe.

In a little you persuade me to act (as) a Christian?

I pray to God both in a little and in a great (while), not only you but also all the ones hearing me today to become similar such as also I myself am except these bonds. (26:25-29)

Paul begins with 'I am not mad', addressing Festus as 'most excellent', adding 'truthful and sound words I declare' (26:25). The verb declare (apophtheggomai) is a verb used in 'dignified and elevated discourse'. Then Paul uses another synonym for 'know', ephistēmi, a literary word in Ionic form (Robertson 1930:452-453): 'For the king knows concerning these things', with an adjectival clause 'to whom also freely I speak' 'for I am persuaded none of these things are hidden; for this is not accomplished in a corner' (26:26). Paul leaves behind all indirect speech now when he asks King Agrippa (ignoring Governor Festus): 'You believe, King Agrippa, in the prophets. I know that you believe' (26:27). But King Agrippa will not be persuaded: 'In a little (time) you persuade me to act (as) a Christian?' (26:28). Paul ends his direct testimony and exhortation with the polite and courteous (Robertson 1930:454, 1934:50,57-58, 86) euchomai [I pray] in

21.Akribestaten [strictest] $(26: 5)$ may be literary Greek (Polhill 1992:500; Witherington 1998:737).

22.Paul uses some classical vocabulary or style - personal construction instead of the impersonal: 'I myself thought with myself' (26:9), katakleiō [shut down like a trap (door] (26:10), 'hard for you to kep kicking ag:9inst gots', (26:14) eneka [because] door] (26:10), 'hard for you to keep kicking against goads', (26:14) eneka [because] (26:21), peiraō [seize] (26:21) and epikouria help] (26:22) (Barrett 1998:1164 Bruce 1990:501, 503-504; Liddell, Scott \& Jones 1968:894; Robertson 1930:445$446,448,450)$. 
the aorist optative: 'I pray to God both in a little and in a great (while), not only you but also all the ones hearing me today to become similar such as also I myself am except these bonds' (26:29). Bruce reflects that 'the whole sentence is very elegantly expressed' (Bruce 1990:506).

Paul has accomplished his goal of proclaiming to the polite and educated elite ${ }^{23}$ of Judea and Rome his change of life and views. He is directly addressing another Jew, Agrippa, but wisely also discrete as he uses literary koine to encase his speech. As a result, Paul receives a positive verdict from Agrippa when he tells Festus that Paul could have been released except that he appealed to Caesar (26:32). The apostle Paul, whilst focusing on the content of his message as an ambassador of good news, has modified his style in Acts 25-26 in light of his educated listeners, as he had modified his style in light of the different situations of the congregations in Corinth, Philippi and Rome. To Festus and Agrippa, Paul came as a diplomat to persuade. As a diplomat, he seeks to be understood and respected by his hearers. Luke, by including this conversation between Festus, Agrippa and Paul, communicated to Theophilus that Paul, as a disciple of Jesus, even during opposition, is empowered by the Spirit to be an effective witness for Jesus. Luke wants Theophilus to follow Jesus' disciples who were empowered by the Spirit to remain witnesses throughout opposition. If Theophilus was indeed a Roman of rank, he would certainly be encouraged by Festus and Agrippa's positive response to the hearing.

\section{Summary}

Basically, 'style' has been defined as how something is said as a means to undergird what is said. Form is related to meaning. Style is a means to understand content. Given that the Bible is literary communication, its authors use many literary techniques. Literary criticism is the analysis of the meaning of a written text by means of the study of the style and how that meaning is communicated by author(s) to reader(s). Style has to do with the choices an author makes amongst linguistic possibilities, whether looking at the larger or smaller aspects of style. This article reminds readers of the Greek New Testament about some of the characteristics of literary koine and how it is present in certain speeches in Acts. Luke records Paul's use of literary Greek as one of Paul's means to be all things to all people so that he might save some.

The 1st century rhetorician, Longinus, believed that 'a great style is the natural outcome of weighty thoughts; and sublime sayings naturally fall to people of spirit' (Longinus, On the Sublime 10). Given that the New Testament was written by people with 'weighty thoughts' and inspired by the powerful and creative God, is it any wonder that New Testament writers have written their narratives and letters with attention to style? What may appear to be superfluous may in fact be a key to the interpretation of a text, to communicating to others, and to appreciating God. Literary studies can be an opportunity, as Spitzer (1948) says:

23. Including rulers, prophesied in 9:15. to retrace the beauty of God in this world ... There are hidden beauties which do not reveal themselves at the first exploratory attempts (as the apologetic theologians know); in fact, all beauty has some mysterious quality which does not appear at first glance ... It is only a frivolous love that cannot survive intellectual definition; great love prospers with understanding. (pp. 24, 30, n. $1,244-245)$

Attention to ways a writer communicates will not only add to the understanding of a message, but it can also serve as a means to worship God. Then indeed the 'apologetic theologians' will know about God's hidden beauties.

\section{Acknowledgements}

Francois Viljoen and Jennifer Creamer for encouraging publication.

\section{Competing interests}

The author declares that he or she has no financial or personal relationships which may have inappropriately influenced him or her in writing this article.

\section{References}

Anderson, J.D., Jr., 1998, Ancient rhetorical theory and Paul, 2nd edn., Peeters, Leuven. (CBET 18).

Aune, D.E., 1987, The New Testament in its literary environment, Westminster, Philadelphia, PA. (LEC).

Barrett, C.K., 1998, A critical and exegetical commentary on the Acts of the Apostles, vol. 2, T\&T Clark, Edinburgh. (ICC)

Betz, H.D., 1979, Galatians, Fortress, Philadelphia, PA.

Betz, H.D., 1985, 2 Corinthians 8 and 9: A commentary on two administrative letters of the Apostle Paul, Fortress, Philadelphia, PA.

Blass, F., DeBrunner, A. \& Funk, R.W., 1961, A Greek grammar of the New Testament and other early Christian literature, University of Chicago Press, Chicago, IL.

Bruce, F.F., 1990, The Acts of the Apostles: The Greek text with introduction and commentary, 3rd edn., Eerdmans, Grand Rapids, MI.

Byron, J., 2003, Slavery metaphors in early Judaism and Pauline Christianity: A traditiohistorical and exegetical examination, Mohr Siebeck, Tübingen. (WUNT 2, Reihe 162).

Caird, G.B., 1980, The language and imagery of the Bible, Westminster, Philadelphia, PA.

Collange, J.-F., 1973, L'Epitre de Saint Paul aux Philippiens, Delachaux and Niestlé, Neuchatel, (Commentaire du Nouveau Testament, 10a).

Collins, R.F., 2008, The power of images in Paul, Liturgical, Collegeville, MN.

Cosby, M.R., 1988, 'The rhetorical composition of Hebrews 11', Journal of Biblical Literature 107(2), 257-273.

Danker, F.W., Bauer, W., Arndt, F.W. \& Gingrich, F.W., 2000, A Greek-English lexicon of the New Testament and other early Christian literature (BDAG), 3rd edn., University of Chicago Press, Chicago, IL.

Dover, K.J., 1960, Greek word order, Cambridge University Press, Cambridge.

Finlan, S., 2004, The background and content of Paul's cultic atonement metaphors, Society of Biblical Literature, Atlanta, GA. (SBL 19).

Kennedy, G.A., 1984, New Testament interpretation through rhetorical criticism, University of North Carolina Press, Chapel Hill, NC. (SR.)

Liddell, H.G., Scott, R. \& Jones, H.S., 1968, A Greek-English lexicon, 9th edn., Clarendon, Oxford.

Longman, T., III, 1987, Literary approaches to biblical interpretation, Zondervan, Grand Rapids, MI. (Foundations of Contemporary Interpretation, 3).

Lyall, F., 1984, Slaves, citizens, sons: Legal metaphors in the epistles, Zondervan, Grand Rapids, MI.

McNeel, J.H., 2014, Paul as infant and nursing mother: Metaphor, rhetoric, and identity in 1 Thessalonians 2:5-8, Society of Biblical Literature, Atlanta, GA. (Early Christianity and its Literature)

Mosteller, F. \& Wallace, D., 1963, 'Inference in an authorship problem', Journal of the American Statistical Association 58, 275-309.

Moulton, J.H., 1908, A grammar of New Testament Greek: Prolegomena, vol. 1, 3rd edn., T\&T Clark, Edinburgh.

Neumann, K.J., 1990, The authenticity of the Pauline epistles in the light of stylostatistical analysis, Scholars, Atlanta, GA. (SBLDS 120). 
Polhill, J.B., 1992, Acts, Broadman, Nashville, TN. (NAC, 26).

Porter, S.E. \& Stamps, D.L. (eds.), 1999, The rhetorical interpretation of Scripture: Essays from the 1996 Malibu Conference, University of Sheffield, Sheffield. (JSNTSup 180).

Robertson, A.T., 1930, The Acts of the Apostles, Broadman, Nashville, TN. (Word pictures in the New Testament, 3).

Robertson, A.T., 1934, A grammar of the Greek New Testament in the light of historical research, Broadman, Nashville, TN

Ryken, L., 1987, Words of life: A literary introduction to the New Testament, Baker, Grand Rapids, MI.

Ryken, L., 1992, Words of delight, 2nd edn., Baker, Grand Rapids, MI.

Ryken, L., Wilhoit, J.C. \& Longman, T., III, (eds.), 1998, Dictionary of biblical imagery, InterVarsity, Downers Grove, IL.

Sampley, J.P. \& Lampe, P. (eds.), 2010, Paul and rhetoric, T\&T Clark, New York.

Schnabel, E.J., 2012, Acts: Zondervan exegetical commentary on the New Testament, Zondervan, Grand Rapids, MI. (Zondervan Exegetical Commentary Series).

Schürer, E., 1973, The History of the Jewish people in the age of Jesus Christ, vol. 1, T\&T Clark, Edinburgh.

Spencer, A.B., 1984, Paul's literary style: A stylistic and historical comparison of II Corinthians 11:16-12:13, Romans 8:9-39, and Philippians 3:2-4:13, University Press of America, Lanham, MD.
Spencer, A.B., 1991, 'Literary Criticism', in D.A. Black \& D.S. Dockery (eds.) New Testament criticism and interpretation, pp. 227-251, Zondervan, Grand Rapids, Ml.

Spitzer, L., 1948, Linguistics and literary history: Essays in stylistics, Princeton University Press, Princeton.

Stanley, C.D., 2004, Arguing with Scripture: The rhetoric of quotations in the letters of Paul, T\&T Clark, New York.

Turner, N., 1976, Style: A grammar of New Testament Greek, vol. 4, T\&T Clark, Edinburgh.

Watson, D.F., 2010, 'The role of style in the Pauline epistles: From ornamentation to argumentative strategies', in J.P. Sampley \& P. Lampe (eds.), Paul and rhetoric, pp. 119-139, T\&T Clark, New York.

Williams, D.J., 1990, Acts, Hendrickson, Peabody, MA. (NIBCNT).

Williams, D.J., 1999, Paul's metaphors: Their context and character, Hendrickson, Peabody, MA.

Winter, B.W., 1993, 'Official proceedings and the forensic speeches in Acts 24-26', in B.W. Winter \& A.D. Clarke (eds.), The book of Acts in its ancient literary setting, pp. 305-336, Eerdmans, Grand Rapids, MI. (BAFCS, 1).

Witherington, B., III, 1998, The Acts of the Apostles: A socio-rhetorical commentary, Eerdmans, Grand Rapids, MI.

Witherington, B., III, 2009, New Testament rhetoric: An introductory guide to the art of persuasion in and of the New Testament, Cascade, Eugene, OR. 